\title{
SPASTIC PARAPLEGIA IN LATHYRIASIS
}

\author{
By Professor Lala Surajnandan Prasad, F.R.C.P.(Edin.), D.C.H.(Lond.), \\ Hon. F.A.A.P.(U.S.A.), F.A.M.S. \\ Department of Pediatrics, P.W. Medical College, Patna-4 (Bihar), India
}

\section{INTRODUCTION}

THE condition of lathyriasis was first investigated on a large scale by Buchanan in India, 1904. Buchanan described cases occurring in the United Provinces during the years of I 886 and I902, where the condition of 'Epidemic Spastic Paralysis' was present in up to 13 per cent of the inhabitants in certain villages. McCarrison (1926) reported that he saw many cases in the Gilgit Agency of Kashmir in 1908, the disease occurring exclusively in males and the diet consisting of a high proportion of L. sativus. Traband and Mouharram (1932) as a result of their investigations of the cases of lathyrism in Syria came to the conclusion that $L$. sativus (khesari) was responsible for the disease.

Chaudhury et al. (1936) described an epidemic of lathyriasis in a remote rural area situated about $250 \mathrm{~km}$. from Calcutta. It first came to the notice of authorities early in 1960 when some apparently healthy persons were seen limping about with the aid of sticks. The affected locality constituted of several hamlets scattered on either side of a river, over an area of 200 square miles. Rice was the staple diet of these inhabitants, with very little khesari (L. sativus). Due to the paddy fields being ruined by deposits of sand and silt resulting from a flood six years previously the inhabitants started to grow khesari instead. As these plants grew so well and cost very little they used them liberally.

Out of 22 cases brought to Calcutta and investigated in the Tropical School of Medicine, all were adult males except for two girls and one boy below 8 years of age. The duration of their illness varied from five months to five years. The onset of actual paralysis of the lower limbs was sudden in 12 cases following some exertion e.g. ploughing, walking a long distance or carrying heavy loads. In others the onset was slow and definite with gradual development of weakness and spasticity of the legs. Cramps and tingling in the legs were present in the majority of cases. Higher cerebral functions and cranial nerves were found to be normal.

\section{MATERIAL}

Patients for this study came from the Children's Outpatient Department and the General Medical wards of the Patna Medical College Hospital. There were three children, three adolescents and one adult ranging in age from 6 to 50 years. All came from a low economic strata of the society and they had invariably reported to the centre because of their inability to walk properly.

\section{METHODS}

A thorough clinical examination was carried out on each patient and the findings noted (Tables I-III). Biochemical and haematological investigations were 
TABLE I

\section{Observation}

\begin{tabular}{|c|c|c|c|c|}
\hline Patient & $\begin{array}{l}\text { Presenting complaints } \\
\text { and duration }\end{array}$ & Dietetic history & Clinical features & Laboratory investigations \\
\hline $\begin{array}{l}\text { I. G. R. } \\
\text { (I8 yrs.) }\end{array}$ & $\begin{array}{l}\text { Difficulty in walking } \\
\text { and weakness in } \\
\text { lower limbs }-2 \text { years }\end{array}$ & $\begin{array}{l}\text { He used to take } \\
\text { Khesari as Dal } \\
\text { (soup) with rice or } \\
\text { bread as his } \\
\text { principal meals for } \\
\text { about two months } \\
\text { prior to appearance } \\
\text { of symptoms }\end{array}$ & $\begin{array}{l}\text { Nervous system: } \\
\text { Gait-Spastic } \\
\text { Sensations-Intact } \\
\text { Cranial nerves-Intact } \\
\text { Upper limbs-Normal } \\
\text { Lower limbs-U.M.N. lesion with } \\
\text { bilateral sustained ankle clonus } \\
\text { C.V.S. and Resp. system-N.A.D. } \\
\text { Abdomen-Liver-I. cm. BCM, tender } \\
\text { Spleen-Not palpable }\end{array}$ & 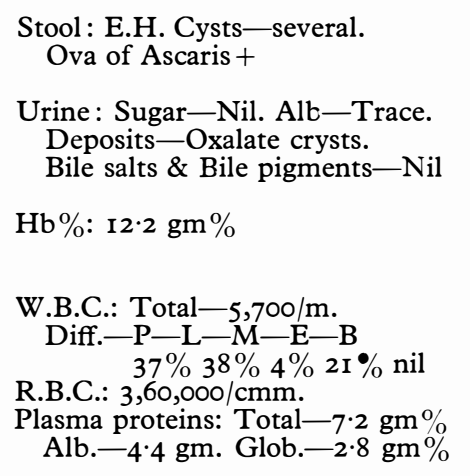 \\
\hline $\begin{array}{l}\text { 2. R. R. } \\
\text { (12 yrs.) }\end{array}$ & $\begin{array}{l}\text { Difficulty in walking } \\
-2 \text { years }\end{array}$ & $\begin{array}{l}\text { He was exclusively } \\
\text { on Khesari for two } \\
\text { months prior to the } \\
\text { onset of symptoms. } \\
\text { He took bread, } \\
\text { sattu, soup and } \\
\text { vegetables made of } \\
\text { Khesari }\end{array}$ & $\begin{array}{l}\text { Nervous system: } \\
\text { Gait-Spastic with tendency of } \\
\text { scissoring of lower limbs. } \\
\text { Sensations-Intact } \\
\text { Cranial nerves-Intact } \\
\text { Upper limbs-Normal } \\
\text { Lower limbs-U.M.N. lesion with } \\
\text { bilateral sustained ankle clonus } \\
\text { C.V.S. and Resp. system-N.A.D. } \\
\text { Abdomen-Liver-I cm. BCM } \\
\text { Spleen-Not palpable }\end{array}$ & $\begin{array}{l}\text { Stool-N.A.D. } \\
\text { Urine: Sugar-Nil. Alb.-Trace } \\
\text { Hb\%-I } 4 \text { gm } \% \\
\text { W.B.C.-Total-8,000/cmm. } \\
\text { Diff.-P-L-M-E-B } \\
\quad 60 \% 37 \% \text { I } \% 2 \% \text { nil } \\
\text { R.B.C. }-3,42,000 / \mathrm{cmm}^{2} \\
\text { Plasma proteins: Total-7.5 gm } \% \\
\text { Alb.-4.7 gm } \% \text { Glob.-2.8 gm. } \\
\text { A:G-I:I.7 }\end{array}$ \\
\hline
\end{tabular}


TABLE II

Observation

\begin{tabular}{|c|c|c|c|c|}
\hline Patient & $\begin{array}{l}\text { Presenting complaints } \\
\text { and duration }\end{array}$ & Dietetic history & Clinical features & Laboratory investigations \\
\hline $\begin{array}{l}\text { 3. S. P. } \\
\text { (I6 yrs.) }\end{array}$ & $\begin{array}{l}\text { Difficulty in walking, } \\
\text { pain in back and } \\
\text { lower limbs and } \\
\text { tingling both upper } \\
\text { limbs-5 months }\end{array}$ & $\begin{array}{l}\text { He used to take } \\
\text { Khesari daily as } \\
\text { soup since } 2 \\
\text { years }\end{array}$ & $\begin{array}{l}\text { Nervous system: } \\
\text { Gait-Spastic } \\
\text { Sensations-Intact } \\
\text { Cranial nerves-Intact } \\
\text { Upper limbs-U.M.N. lesion } \\
\text { C.V.S. and Resp. system-N.A.D. } \\
\text { Abdomen-Nothing particular }\end{array}$ & 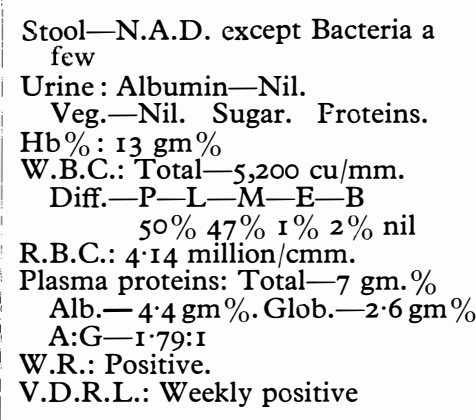 \\
\hline $\begin{array}{l}\text { 4. B. S. } \\
\text { (IO yrs.) }\end{array}$ & $\begin{array}{l}\text { Difficulty in walking } \\
\text { - IO days }\end{array}$ & $\begin{array}{l}\text { He used to take } \\
\text { Khesari as Dal } \\
\text { (soup) throughout } \\
\text { the year }\end{array}$ & $\begin{array}{l}\text { Nervous system: } \\
\text { Gait-Spastic with tendency of } \\
\text { scissoring of lower limb } \\
\text { Sensations-Intact } \\
\text { Cranial nerves-Intact } \\
\text { Upper limbs-Normal } \\
\text { Lower limb-U.N.M. lesion } \\
\text { C.V.S. and Resp. system-N.A.D. } \\
\text { Abdomen-N.A.D. }\end{array}$ & $\begin{array}{l}\text { Stool: Protozoa-Nil Bacteria }++ \\
\text { Urine: Sugar-Nil. Alb.-Trace. } \\
\text { Epith. Cell-a few } \\
\text { Hb\%: I } 2.4 \text { gm } \% \text {. } \\
\text { W.B.C.: Total-7,550 cm/mm. } \\
\text { Diff. -P-L-M-E-B } \\
\text { 6r } \% 28 \% 2 \% 9 \% \text { nil } \\
\text { R.B.C.: } 4.6 \mathrm{million} / \mathrm{cmm} . \\
\text { Plasma proteins: Total-6.9 gm. } \% \\
\text { PA.b. } 4.05 \text { gm. } \% \text { Glob.- } \\
\text { 2.85 gm } \% . \text { A:G - I.5 I:I }\end{array}$ \\
\hline $\begin{array}{l}\text { 5. Y. S. } \\
\text { (15 yrs.) }\end{array}$ & $\begin{array}{l}\text { Difficulty in walking } \\
\text { and weakness lower } \\
\text { limbs-6 months }\end{array}$ & $\begin{array}{l}\text { He used to take } \\
\text { Khesari as Dal } \\
\text { (soup) throughout } \\
\text { the year }\end{array}$ & $\begin{array}{l}\text { Nervous system: } \\
\text { Gait-Spastic with tendency of } \\
\text { scissoring of lower limbs. } \\
\text { Sensations-Intact } \\
\text { Cranial nerves-Intact } \\
\text { Upper limb-Normal } \\
\text { Upper limb-Normal } \\
\text { Lower limbs-U.M.N. lesion } \\
\text { C.V.S. and Resp. system-N.A.D. } \\
\text { Abdomen-N.A.D. }\end{array}$ & $\begin{array}{l}\text { Stool: EH cysts a few, others nil. } \\
\text { Bacteria-+ }+ \\
\text { Urine: Sugar-Nil. Alb.-Nil. } \\
\text { Hb\%: I I.8 gm } \% \\
\text { W.B.C.: Total-9,250 cu/mm. } \\
\text { Diff. - N-L-E-M-B } \\
59 \% 32 \% 8 \% \text { I } \% \text { nil } \\
\text { R.B.C.: } 4.15 \mathrm{million} / \mathrm{cmm} \text {. } \\
\text { Plasma proteins: Total-6.9 gm } \% \text {. } \\
\text { Alb. }-3.97 \text { gm } \% \text { Glob.- } \\
\text { 2.93 gm } \% \text { A:G-I.35:I }\end{array}$ \\
\hline
\end{tabular}


TABLE III

\section{Observation}

\begin{tabular}{|c|c|c|c|c|}
\hline Patient & $\begin{array}{l}\text { Presenting complaints } \\
\text { and duration }\end{array}$ & Dietetic history & Clinical features & Laboratory investigations \\
\hline \multirow[t]{2}{*}{$\begin{array}{l}\text { 6. N. M. } \\
\text { (50 yrs.) }\end{array}$} & \multirow[t]{2}{*}{$\begin{array}{l}\text { Difficulty in walking } \\
\text { and weakness in } \\
\text { lower limbs-I } 4 \\
\text { months }\end{array}$} & \multirow[t]{2}{*}{$\begin{array}{l}\text { He used to take } \\
\text { Khesari as Dal } \\
\text { (soup) throughout } \\
\text { the year }\end{array}$} & \multirow{2}{*}{$\begin{array}{l}\text { Nervous system: } \\
\text { Gait-Spastic } \\
\text { Sensation-Intact } \\
\text { Cranial nerves-Intact } \\
\text { Upper limbs-Normal } \\
\text { Lower limbs-U.M.N. lesions } \\
\text { C.V.S. and lung-N.A.D. } \\
\text { Abdomen-N.A.D. }\end{array}$} & $\begin{array}{l}\text { Stool: Protozoa-Nil. Others- } \\
\text { Nil. Bacteria-+ } \\
\text { Urine: Sugar-Nil. Alb.-None }\end{array}$ \\
\hline & & & & $\begin{array}{l}\mathrm{Hb} \%: \mathrm{I} 3.4 \mathrm{gm} \% \\
\text { W.B.C.: } \mathrm{II}, 500 / \mathrm{mm} . \\
\text { Diff. } \mathrm{N}-\mathrm{L}-\mathrm{E}-\mathrm{M}-\mathrm{B} \\
\quad 68 \% 26 \% 4 \% 2 \% \text { nil } \\
\text { R.B.C.: } 4.68 \mathrm{million} / \mathrm{cmm} . \\
\text { Plasma protein: Total }-7.3 \mathrm{gm} \% \text {. } \\
\text { Alb. } 4 . \mathrm{I} 8 \mathrm{gm} \% \text {. Glob. }- \\
\text { 3.12 } \mathrm{gm} \% \text { A:G-I.34:I }\end{array}$ \\
\hline $\begin{array}{l}\text { 7. A. S. } \\
\text { (6 yrs.) }\end{array}$ & $\begin{array}{l}\text { Difficulty in walking } \\
\text { and weakness in both } \\
\text { the lower limbs }\end{array}$ & $\begin{array}{l}\text { He used to take } \\
\text { Khesari as Dal } \\
\text { (soup) throughout } \\
\text { the year }\end{array}$ & $\begin{array}{l}\text { Nervous system: } \\
\text { Gait-Spastic } \\
\text { Sensation-Intact } \\
\text { Cranial nerves-Intact } \\
\text { Upper limbs-Normal } \\
\text { Lower limbs-U.M.N. lesions } \\
\text { C.V.S. and lung-N.A.D. } \\
\text { Abdomen-N.A.D. }\end{array}$ & 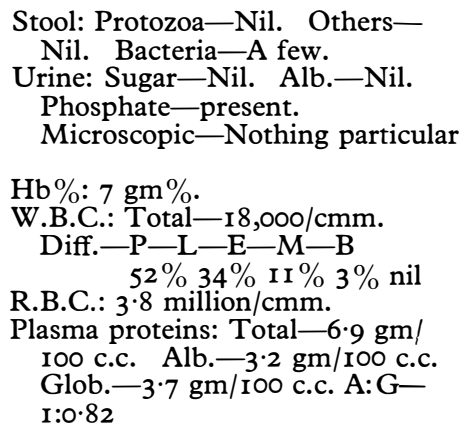 \\
\hline
\end{tabular}


done in the UNICEF-aided laboratory attached to the Department of Pediatrics. Experimental work on chicks was carried out at the Rajendra Memorial Research Institute of Medical Sciences, Patna. (Refer to paper by Dr. R. K. Sharan.)

\section{DISCUSSION}

Of all the states in India, the incidence of lathyriasis appears to be highest in Bihar. Most of the patients are poor and have to walk to the Outpatient Department for treatment. Lathyriasis is characterised by spastic weakness of both lower limbs which may be of sudden or gradual onset. The gait of persons suffering from this condition is quite typical, i.e. a spastic gait with a tendency to scissoring.
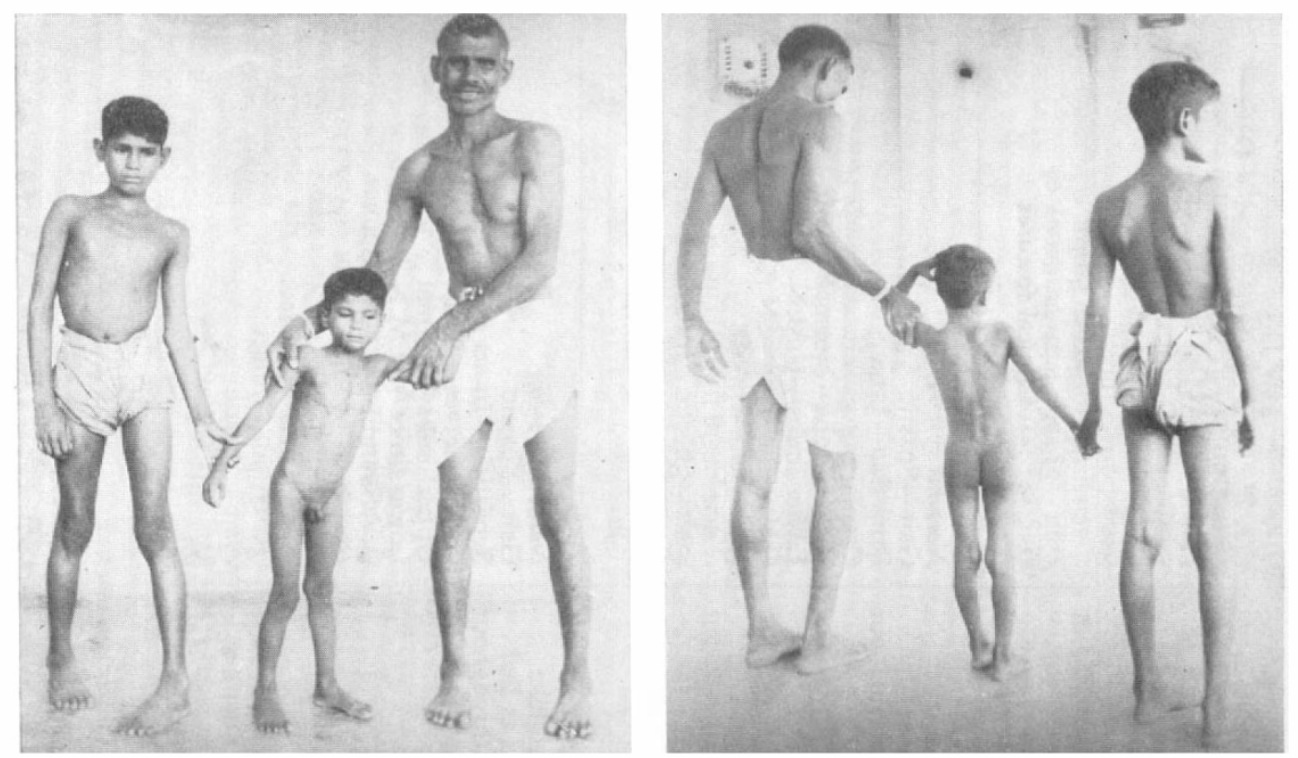

FIGS. I and 2

Father and two sons suffering from spastic paraplegia in lathyriasis.

This condition leaves the sufferer a lifelong disability which affects both children and adults.

An analysis of seven cases of lathyriasis in the present series showed that this disease can occur in both children and adults ranging in age from 6-50 years; mostly confined to the males. As regards the mode of onset, which was acute in two cases and gradual in five, one cannot be always definite as these patients were unable to give a precise history. Analysis of the dietetic history in all the seven cases showed that the diet consisted of 'Khesari Dal' and bread for quite a few months in a year along with the staple diet, viz. rice and vegetables. These patients were forced to take bread and soup made of khesari on account of sheer poverty.

Clinical analysis showed that none of the cases had either visceral or sensory disturbances and the higher cerebral functions were well preserved. In some cases several members of one family were affected and it was not unusual to come across several cases in one village. 
The clinical pattern in all cases of lathyriasis is quite constant, and this observation has also been reported by other workers. They exhibit the same type of spasticity and limping with a tendency to scissoring (figs. I and 2).

However, before the paraplegic symptoms appear, there is a phase during which some of them complain of cramps or tingling. The symptoms progress gradually, and after a few months the disability is quite obvious on account of a spastic gait. Fortunately, the weakness and spasticity are confined to the lower limbs thus enabling these poor individuals to earn their livelihood. The knee and ankle jerks are brisk and the plantar response is bilaterally extensor. There is no loss of sensation and the sense of position and vibration is intact. In some cases, well marked patellar and ankle clonus is present. All these neurological findings put the condition of lathyriasis in the category of spastic paraplegia, the exact pathogenesis of which is unknown in humans.

\section{SUMMARY}

Seven cases of lathyriasis occurring in both children and adults have been described. The role of diet in producing this type of spastic paraplegia has been stressed. The exact pathogenesis being unknown, the experimental work resulting in production of spastic paraplegia in chicks by injecting chemical extract of L. sativus is reported in R. K. Sharan's paper.

\section{REFERENCES}

Anderson, L. A. P., Howard, P. \& Simmonsen, J. L. (1925). Ind. F. med. Res. 12, 613-643. Bhagvat, K. (I946). Ind. F. med. Res. 34, 299-304.

Buchanan, A. (I927). Govt. Press, Nagpur, I-7I.

De, H. N. \& DatTa, P. K. (I948). Linn. and Cult. I4, I59-I60.

Dwivedi, M. P. \& Prasad, B. G. (I96I). Ind. F. med. Res. 52, 8I.

Ganpathy, K. T. \& Dwivedi, M. P. (I96I). Indian Council of Medical Research Publication, Gandhi Memorial Hosp. Rewa.

Ganpathy, K. T., Dwivedi, M. P., Nagrahan, V. \& Dikshitulu, V. N. (I963). Ind. $\mathcal{f}$. med. Res. 5I, 865 .

MCCARRISON, R. (1926). Ind. F. med. Res. I4, 379.

MCCARRISON, R. (I928). Ind. F. med. Res. I 5, 797.

McCarrison, R. \& Krishna, B. G. (I934). Ind. F. med. Res. 22, 65-66.

SELYe, H. (I957). Rev. Canad. Biol. I6, I.

SHOURIE, K. L. (I945). Ind. F. med. Res. 33, 239-247. 